\title{
Effect of rotary instrumentation and of the association of calcium hydroxide and chlorhexidine on the antisepsis of the root canal system in dogs
}

\section{Efeito da instrumentação automatizada e da associação hidróxido de cálcio e clorexidina na anti-sepsia de canais radiculares de cães}

\author{
Janir Alves Soares* \\ Mario Roberto Leonardo** \\ Léa Assed Bezerra da Silva*** \\ Mario Tanomaru Filho**** \\ Izabel Yoko Ito*****
}

\begin{abstract}
This study aimed at evaluating the antisepsis of the root canal system (RCS) and periapical region (PR) provided by rotary instrumentation associated with chlorhexidine + calcium hydroxide as intracanal medicament. Chronic periapical lesions were induced in 26 pre-molar roots in two dogs. After microbiological sampling, automatic instrumentation using the Profile system and irrigation with 5.25\% sodium hypochlorite solution, with a final rinse of $14.3 \%$ EDTA followed by profuse irrigation with physiological saline were carried out in 18 root canals. After drying the canals, a paste based on calcium hydroxide associated with a $2 \%$ chlorhexidine digluconate solution was placed inside them. After 21 days, the medication was removed, leaving the root canals empty and coronally sealed. After 96 hours, a final microbiological sample was obtained, followed by histomicrobiological processing by the Brown \& Brenn method. Eight untreated root canals represented the control group (C-G). Based on the Mann-Whitney test at a confidence level of $5 \%(p<0.05)$, the procedures of antisepsis used offered significant efficacy $(\mathrm{p}<0.05)$ resulting in $100.0 \%$ of the canals free of microorganisms. In the $\mathrm{C}-\mathrm{G}$, an elevated incidence of various microbial morphotypes was confirmed in all sites of the RCS, with the presence of microbial colonies in the periapical region. In contrast, the experimental group showed a similar pattern of infection in the RCS, although less intense and a reduced level of periapical infection $(\mathrm{p}<0.05)$. It was concluded that adequate instrumentation followed by the application of calcium hydroxide + chlorhexidine offered significant elimination of microorganisms.
\end{abstract}

DESCRIPTORS: Endodontics; Microbiology; Calcium hydroxide; Chlorhexidine.

RESUMO: Este estudo objetivou avaliar a anti-sepsia do sistema de canais radiculares (SCR) e da região periapical (RP) proporcionada pela instrumentação automatizada associada a medicação intracanal à base de hidróxido de cálcio + clorexidina. Lesões periapicais crônicas foram induzidas em 26 raízes de pré-molares de dois cães. Após amostragem microbiológica, procedeu-se à instrumentação automatizada de 18 canais radiculares (CR) utilizandose o sistema Profile e a solução de hipoclorito de sódio a 5,25\%, com irrigação final com EDTA a 14,3\%, seguida de irrigação profusa com soro fisiológico. Após se secarem os canais, foi colocada em seu interior uma pasta à base de hidróxido de cálcio P.A. associada à solução de digluconato de clorexidina a $2 \%$. Transcorridos 21 dias, removeu-se a medicação, deixando-se os CR vazios e selados coronariamente. Após 96 horas, obteve-se a amostra microbiológica final e realizou-se o processamento histomicrobiológico pelo método de Brown \& Brenn. Oito CR sem tratamento endodôntico representaram o grupo controle (G-C). Pelo teste de Mann-Whitney ao nível de 5\% (p < 0,05), os procedimentos de anti-sepsia utilizados proporcionaram significativa eficácia ( $p<0,05)$, resultando em 100,0\% de CR livres de microrganismos. No G-C, verificou-se elevada incidência de vários morfotipos microbianos em todos os sítios do SCR e colônias microbianas na RP. Em contrapartida, no grupo experimental, verificou-se um padrão de infecção do SCR similar, mas menos intenso e reduzida presença de infecção extrarradicular $(p<0,05)$. Concluiu-se que a adequada instrumentação seguida da aplicação do hidróxido de cálcio + clorexidina proporcionou significativa eliminação de microrganismos.

DESCRITORES: Endodontia; Microbiologia; Hidróxido de cálcio; Clorexidina.

\footnotetext{
* Professor of Endodontics, Federal University of the Valleys of Jequitinhonha and Mucuri.

** Full Professor of Endodontics; ****Associate Professor of Endodontics - School of Dentistry of Araraquara, São Paulo State University.

*** Full Professor of Pediatric Dentistry, School of Dentistry of Ribeirão Preto; *****Full Professor of Microbiology, School of Pharmaceutical Sciences of Ribeirão Preto - University of São Paulo.
} 
Soares JA, Leonardo MR, Silva LAB, Tanomaru Filho M, Ito IY. Effect of rotary instrumentation and of the association of calcium hydroxide and chlorhexidine on the antisepsis of the root canal system in dogs. Braz Oral Res 2006;20(2):120-6.

\section{INTRODUCTION}

The response of the immunological system to infection of the root canal system and of the tissues adjacent to the apical foramen results in the formation and perpetuation of periapical pathology $^{2,11,15,18,19}$. Root canal therapy has antisepsis as one of the objectives. The action of files and irrigation solutions have only a partial and temporary effect upon microorganisms limited to the principal root canal ${ }^{2,3,18}$. Consequently, after adequate cleaning and shaping of the root canals, the application of dressings is recommended, usually with calcium hydroxide ${ }^{1,2,5-11,13,18,22}$, which has a complementary antiseptic action on the microorganisms remaining in the root canal system and apical cement lacunae.

Vehicles used with the calcium hydroxide paste may be water soluble, aqueous ${ }^{2,17,23}$ viscous $^{11-}$ ${ }^{13}$, inert or with an antiseptic action ${ }^{1,2,13,21,22,24}$. Endodontic infection diffuses through the root canal system and is polymicrobial ${ }^{5,15}$. Calcium hydroxide cannot be considered effective against all microorganisms ${ }^{5,6,16}$. Therefore, the vehicles for calcium hydroxide must allow satisfactory dissociation and diffusion of calcium and hydroxyl ions and biocompatibility. Chlorhexidine has been used as vehicle for $\mathrm{Ca}(\mathrm{OH})_{2}{ }^{5,6,21}$. It is a biguanide used for irrigation of the root canals ${ }^{5,6,14}$, irrigation of the operating field in periodontal and periapical surgery ${ }^{4,10}$. For long, it has been used for supra- and sub-gingival biofilm control in the form of mouthwashes, irrigation solutions or sustained release devices ${ }^{7,9,14}$. Its concentrations vary between 0.12 and $2.0 \%$, and it is effective against gram-positive and gram-negative obligate anaerobic and facultative microorganisms $\mathrm{s}^{8,14,24}$.

Chlorhexidine has a broad antimicrobial spectrum and calcium hydroxide is one of the most commonly used intracanal medicaments. Therefore, the objective of this study was to evaluate the antiseptic effect of rotary instrumentation followed by the action of a paste based on calcium hydroxide associated with a solution of $2 \%$ chlorhexidine digluconate in dog teeth with experimentally induced periapical lesions.

\section{MATERIAL AND METHODS}

This study was conducted on 13 upper and lower premolars from two dogs aged 1 year, totalizing 26 root canals $(\mathrm{n}=26)$. For sedation, $2.0 \mathrm{ml}$ of Rompum (Bayer S/A - Veterinary products - Ind.
Bras., Porto Alegre, RS, Brazil) were injected intramuscularly, at a dosage of $3.0 \mathrm{mg} / \mathrm{Kg}$ of body weight. The intravenous anesthesia used was Thiopental (Thionembutal-Abbott Laboratórios do Brasil Ltda., Rio de Janeiro, RJ, Brazil), representing a dosage of $15 \mathrm{mg} / \mathrm{Kg}$. After coronal access to the root canals, radiography was made to obtain the working length and the pulp was removed with a \#25 Hedströen file (Hedströen File Colorinox Dentsply/Maillefer, Ballaigues, Switzerland). The enlargement of the apical delta was achieved by using K-files until file \#30, with the objective of establishing a standardized apical opening. The root canals remained exposed to the oral cavity for seven days, after which the coronal cavity was sealed with zinc oxide-eugenol cement (S.S. White, Rio de Janeiro, RJ, Brazil) to allow time for the induction of periapical lesions. Standardized radiographs were taken to monitor the development of radiolucent periapical areas, which usually occurred in approximately 60 days.

The operative procedures were undertaken under rubber dam isolation, following operating field antisepsis with $0.3 \%$ iodine alcohol solution. After removing the temporary coronal filling, the first microbiological samples were obtained from the root canals, using 3 sterilized absorbent paper points that were transferred to test tubes, containing $1.5 \mathrm{ml}$ of reduced transport fluid (RTF). Rotary instrumentation was undertaken using the Profile system (Dentsply/Tulsa Dental Products, Oklahoma, USA) with orifice shapers and \#15 to \#80 $\mathrm{Ni}$-Ti files with a taper of 0.04 and 0.06 , using a crown-down procedure. After each file change, irrigation with $3.6 \mathrm{ml}$ of the hypochlorite solution was made using a syringe and a $27 \mathrm{G}$ needle. The apical foramen patent was obtained with a \#30 K-file. The apical stop was enlarged to \#60 and was located $1.5 \mathrm{~mm}$ from the radiographic apex. After removing the smear layer with buffered 14.3\% EDTA solution (Biodinâmica Química Ltda., Ibiporã, PR, Brazil), which was agitated with a K-file for $3 \mathrm{~min}$, followed by $5.25 \%$ sodium hypochlorite solution, the root canals were then irrigated with $3.6 \mathrm{ml}$ of physiological saline, dried with paper points and a paste was prepared, using $0.9 \mathrm{~g}$ of calcium hydroxide (Labsynth Ltda., São Paulo, SP, Brazil) and $1 \mathrm{ml}$ of a $2 \%$ chlorhexidine gluconate solution (FGM Produtos Odontológicos, Joinville, SC, Brazil), which was applied to the root canals by means of a spiral paste-filler, followed by coronal sealing with a zinc oxide-eugenol cement (S.S.White, Rio de Janeiro, RJ, Brazil). After 21 days, the intra- 
Soares JA, Leonardo MR, Silva LAB, Tanomaru Filho M, Ito IY. Effect of rotary instrumentation and of the association of calcium hydroxide and chlorhexidine on the antisepsis of the root canal system in dogs. Braz Oral Res 2006;20(2):120-6.

canal paste was removed with irrigation using a detergent (Tergentol, lauryl diethyleneglycol ether sodium sulfate, Searle do Brasil Ltda., São Paulo, SP, Brazil) associated with a K-file \#60. After this, the root canals were dried and left empty. The coronal opening was sealed with a zinc oxide-eugenol cement. Eight untreated root canals represented the control group. After four days, a final microbiological sample was taken and the dogs were sacrificed by anesthetic overdose ${ }^{11,22}$.

The tubes containing the microbiological samples were processed. The following culture media were used: blood agar (BA) (Difco, MI, USA); mitissalivarius agar (Ms) (Difco, MI, USA); bacitracin sacarose agar (SB20) (Difco, MI, USA); MacConkey agar (Mc) (Difco, MI, USA) and hypertonic egg yolk agar (Ni) (Difco, MI, USA). Approximately $3.0 \mathrm{ml}$ of thioglycollate broth (Tio's) without indicator and without dextrose (Difco, Detroit, MI, USA) were added to the tubes containing the suspensions. Anaerobic incubation followed for 7 days, and then microaerophilic and aerobic conditions were maintained for 48 hours, at $37^{\circ} \mathrm{C}$. The BA medium with added hemine $(5 \mu \mathrm{g} / \mathrm{mL})$ and menadione $(0.5 \mu \mathrm{g} / \mathrm{mL})$ (Difco, MI, USA) was used to recover obligate anaerobic microorganisms. The Ms Medium permitted the growth of viridans streptococci (S. sanguis, S. mitis, $S$. salivarius and $S$. mutans). The Ni, SB20 and Mc media permitted the growth of Staphylococcus aureus, streptococci of the group mutans and gram-negative facultative enteric bacilli respectively. The colony forming units (CFUs) were measured using a stereoscopic microscope.

After histological processing, semi-serial slices were obtained with $6 \mu \mathrm{m}$ thickness and stained with Brown $\&$ Brenn method. The presence of microorganisms was evaluated in the $2 \mathrm{~mm}$ region of the apex, as well as in the main root canal, ramifications of the apical delta and secondary canals, cement lacunae or apical cementoplasts, dentinal tubules, areas of cement resorption and the periapical lesion. The results were analyzed with the tests of Kruskal-Wallis and Mann-Whitney (U Test) with a level of significance established at $5 \%(\mathrm{P}<0.05)$.

\section{RESULTS}

The root canals of the control group and the initial sample of the experimental group showed elevated numbers of CFUs of obligate anaerobes, aerobes and viridans streptococci (Table 1). Four days after endodontic treatment, an absence of microbial growth was observed in $100.0 \%$ of the samples. One fistula present at the beginning of the treatment had been clinically repaired after 21 days. Black pigmented producing bacilli, gramnegative enteric bacteria and streptococci of the group mutans were not identified.

One hundred and sixty histological sections were analyzed from the control group (Table 2) including ramifications of the apical delta, cement lacunae and the walls of the root canals where

TABLE 1 - Average of CFUs in root canals before and 4 days after the application of calcium hydroxide $+2 \%$ chlorhexidine paste.

\begin{tabular}{|c|c|c|c|c|c|c|c|c|}
\hline \multirow[b]{2}{*}{ Group } & \multicolumn{4}{|c|}{ Before Endodontic Treatment } & \multicolumn{4}{|c|}{ After Endodontic Treatment } \\
\hline & $\begin{array}{c}\text { Obligate } \\
\text { Anaerobes }\end{array}$ & Aerobes & $\begin{array}{c}\text { viridans } \\
\text { Streptococci }\end{array}$ & Tio’s & $\begin{array}{c}\text { Obligate } \\
\text { Anaerobes }\end{array}$ & Aerobes & $\begin{array}{c}\text { viridans } \\
\text { Streptococci }\end{array}$ & Tio's \\
\hline Experimental & $1,323,200$ & 130,920 & 103,309 & + & 0 & 0 & 0 & - \\
\hline Control & $3,237,750$ & 687,750 & 892,250 & + & & & & \\
\hline
\end{tabular}

TABLE 2 - Distribution of microorganisms in the apical 2 millimeters of the root canal system and periapical region of the control and experimental groups.

\begin{tabular}{|c|c|c|c|c|c|c|}
\hline \multirow[b]{2}{*}{ Groups } & \multicolumn{6}{|c|}{ Regions Evaluated Histomicrobiologically } \\
\hline & Apical Delta & $\begin{array}{l}\text { Cement } \\
\text { Lacunae }\end{array}$ & $\begin{array}{l}\text { Root Canal } \\
\text { Walls }\end{array}$ & $\begin{array}{l}\text { Dentinal } \\
\text { Tubules }\end{array}$ & $\begin{array}{l}\text { Areas of Cement } \\
\text { Resorption }\end{array}$ & $\begin{array}{l}\text { Periapical } \\
\text { Region }\end{array}$ \\
\hline Control ( $\mathrm{n}=8$ roots) & $8(100.0 \%)$ & $8(100.0 \%)$ & $8(100.0 \%)$ & $8(100.0 \%)$ & $4(50.0 \%)$ & $7(87.5 \%)$ \\
\hline $\begin{array}{l}\mathrm{Ca}(\mathrm{OH})_{2} \text { P.A. }+2 \% \mathrm{CHX} \\
(\mathrm{n}=18 \text { roots })\end{array}$ & $17 \quad(94.4 \%)$ & $15 \quad(83.3 \%)$ & $14 \quad(77.8 \%)$ & $13 \quad(72.2 \%)$ & 3 (16.7\%) & 5 (27.8\%) \\
\hline
\end{tabular}

CHX = chlorhexidine digluconate. 
Soares JA, Leonardo MR, Silva LAB, Tanomaru Filho M, Ito IY. Effect of rotary instrumentation and of the association of calcium hydroxide and chlorhexidine on the antisepsis of the root canal system in dogs. Braz Oral Res 2006;20(2):120-6.
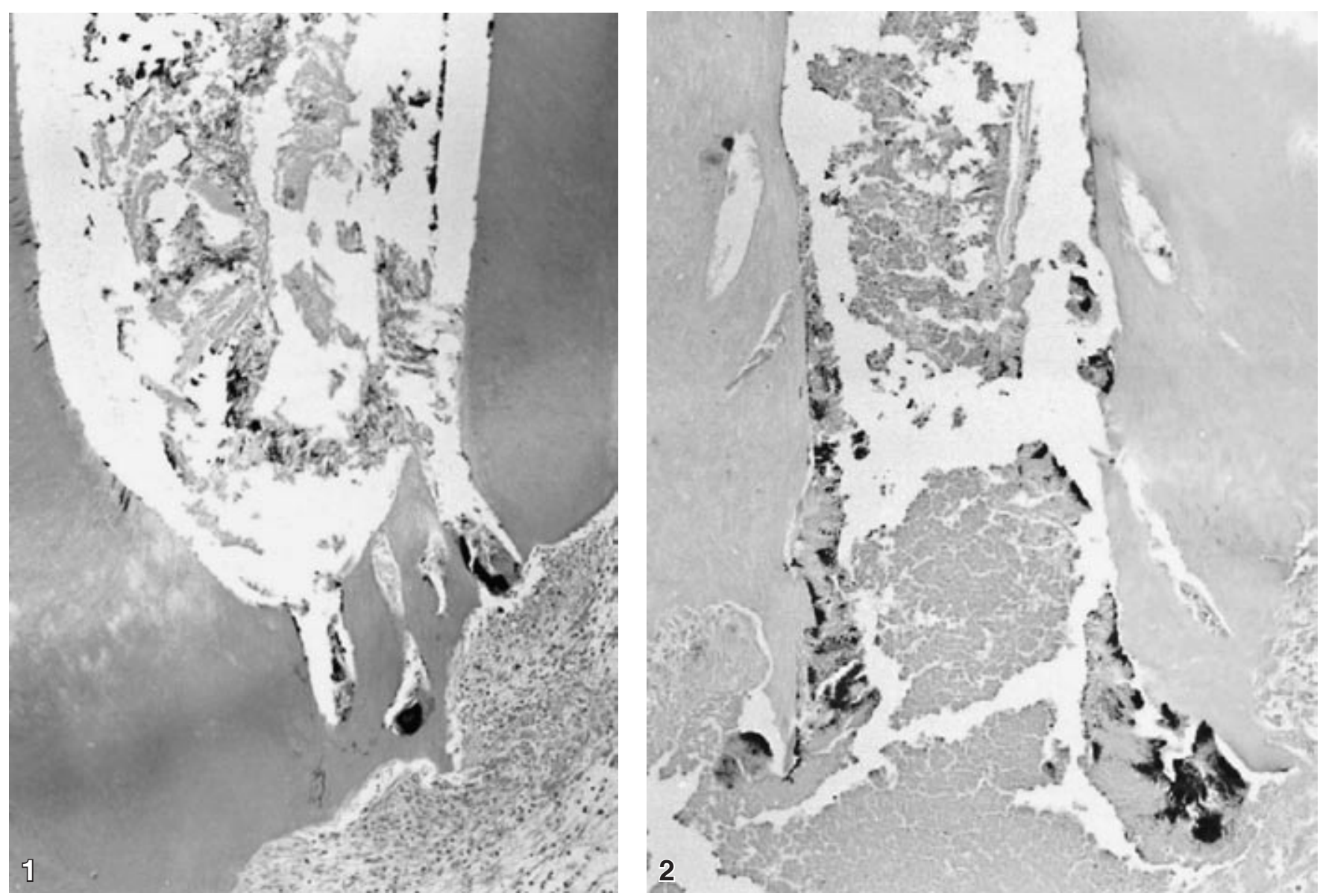

FIGURES 1 AND 2 - Root apical region with microorganisms in the root canal and in the ramifications of the apical delta. Brown \& Brenn - Olympus - 100 X (1). Root apical region with microorganisms on the root canal walls. Brown \& Brenn - Olympus - 60 X (2).

dense aggregations of microorganisms were found in $100.0 \%$ of the samples. These microorganisms formed biofilms, mainly on the walls of the root canals, apical delta canals and the areas of apical cement resorption (Figure 1). Microorganisms were also seen in the apical region in $87.5 \%$ of the roots. In $50.0 \%$ of the specimens, biofilms were seen in areas of cement resorption (Figure 2).

Of the 18 endodontically treated roots, 304 histological slices were obtained. Table 2 shows the distribution of microorganisms in the root canal systems. The greatest incidence of microorganisms was found in the apical delta and cement lacunae (94.4\% and $83.3 \%$, respectively). The walls of the root canals showed the presence of microorganisms in $77.8 \%$ of the samples, and $72.2 \%$ in the dentinal tubules. Only 3 roots $(16.7 \%)$ showed microorganisms in areas of apical resorption (cement erosion). In the periapical region bacteria were observed in only $27.8 \%$ of the samples. As seen in
Figures 3 and 4, the most frequent morphotypes identified were cocci, bacilli and gram-positive filaments. Compared to the control group, there was a similar pattern of infection in the root canal system, although less intense and with a greater incidence of gram-positive morphotypes. The experimental group showed a significant reduction of extraradicular infection $(\mathrm{p}<0.05)$.

\section{DISCUSSION}

Regarding the microbiological point of view, the endodontic procedures eliminated $100.0 \%$ of the microorganisms from the root canals, or left less than $30 \mathrm{CFU} / \mathrm{mL}$ per sample, which is the limit of detection by the culture method. Such a standard of antisepsis resulted from the cleaning and shaping of the root canals; the irrigation system; the concentration, quantity and dissolving action of the $5.25 \%$ sodium hypochlorite solution as well 
Soares JA, Leonardo MR, Silva LAB, Tanomaru Filho M, Ito IY. Effect of rotary instrumentation and of the association of calcium hydroxide and chlorhexidine on the antisepsis of the root canal system in dogs. Braz Oral Res 2006;20(2):120-6.
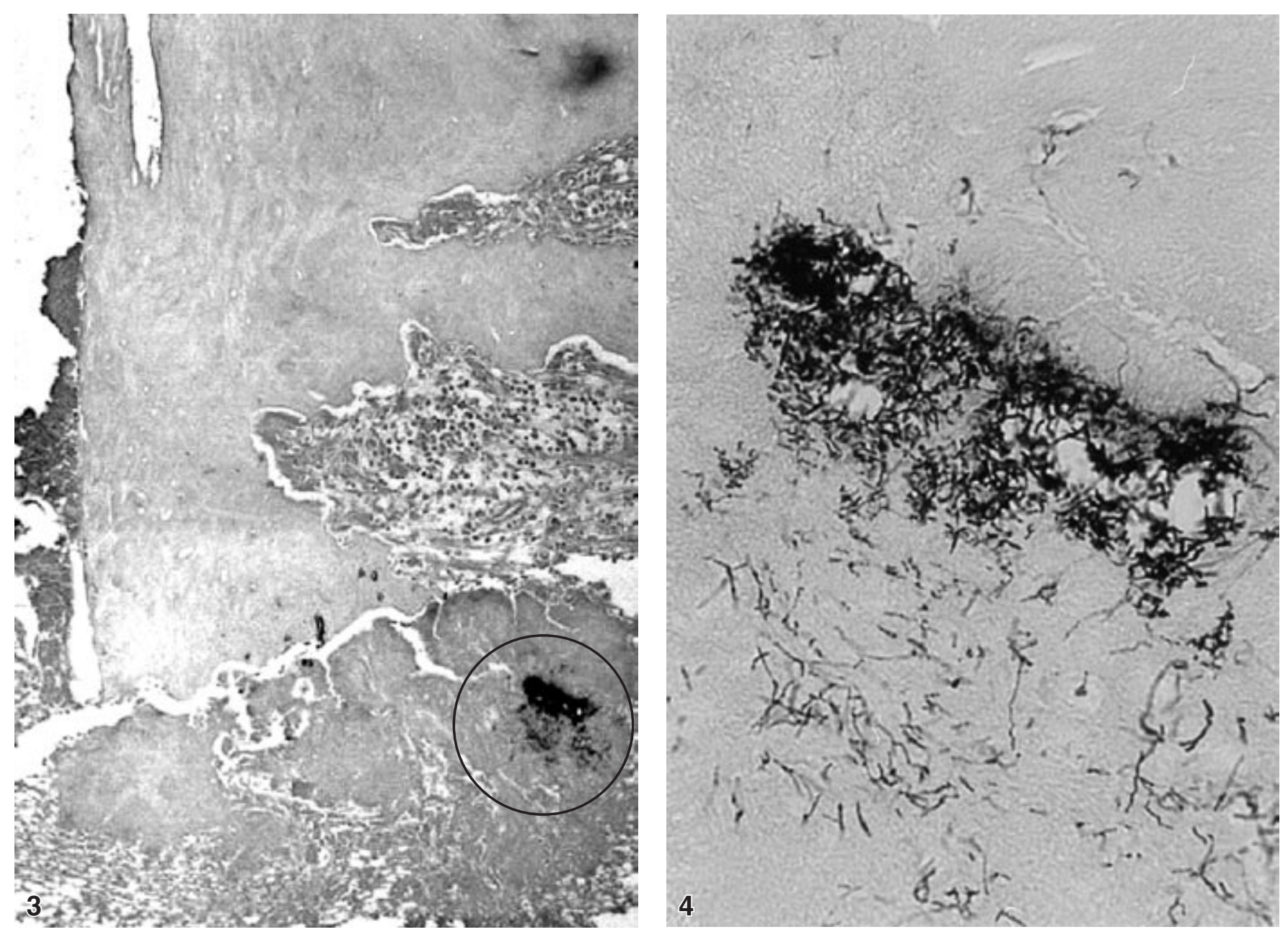

FIGURES 3 AND 4 - Root apical region with microorganisms on the root apex. Brown \& Brenn - Olympus - 100 X (3). Greater magnification of figure 3 (circle). Presence of Gram-positive microorganisms in the apical cementum gaps. Brown \& Brenn - Olympus - 400 X (4).

as their antimicrobial effectiveness ${ }^{3,4,18}$, complemented by the proven antiseptic action of calcium hydroxide $\mathrm{e}^{1,2,7,22-24}$ and chlorhexidine $\mathrm{e}^{5,6,8,21,24}$.

The microorganisms remaining on the dentinal walls are the first to suffer the action of hydroxyl ions from calcium hydroxide. However, to eliminate those situated in dentinal tubules, secondary canals and apical cementum, the ions need to diffuse and reach sufficient concentration, and overcome various physical and biological barriers ${ }^{17,20}$. These facts retard the process of dentine alkalinisation, where 2 to 3 weeks are necessary to obtain a plateau of $\mathrm{pH} 9$ to 10 in the most external parts of the roots ${ }^{17}$.

The microbiological sample taken immediately after the application of the dressing relates only to the antisepsis of the main root canal, and does not reflect on the real microbiological condition of the root canal system. Thus, after removal of the intracanal medication, the occlusal sealing was replaced and the second microbiological sample was obtained 96 hours later, the period in which the remaining microorganisms may have time to reach the root canal ${ }^{2,18}$. In the present study, considering microbial culture, the mechanical preparation and the intracanal dressing offered ideal conditions for the obturation of the root canals ${ }^{2}$, as they were $100 \%$ free of bacteria 4 days after the chemicalmechanical disinfection.

The microorganisms may develop mechanisms of resistance and evasion of the immunological defense and survive in the periapical tissues, forming biofilms. Using microbial culture and the electron microscope ${ }^{12,15}$, it may be possible to verify the elevated incidence of microorganisms in apical granulomas in the majority of persistent periapi- 
Soares JA, Leonardo MR, Silva LAB, Tanomaru Filho M, Ito IY. Effect of rotary instrumentation and of the association of calcium hydroxide and chlorhexidine on the antisepsis of the root canal system in dogs. Braz Oral Res 2006;20(2):120-6.

cal lesions ${ }^{2,15}$. Corroborated by other studies ${ }^{11,19}$, the histomicrobiological methodology used allowed identification of the topographical distribution of microorganisms. Thus, the control group showed innumerable microorganisms in all the sites of the root canal system and in the periapical region, in the proximities of the foramen and areas of cement resorption, where clearly visible biofilms, containing gram-positive and negative cocci, bacilli and filaments, were immersed in an amorphous extracellular material. Similar reports have been made using a scanning electron microscope ${ }^{13,15}$.

Compared to the control group, after biomechanical preparation and application of calcium hydroxide associated with chlorhexidine, no significant difference was found in the standard of antisepsis of the root canal systems, though a notably lower intensity of infection was observed. In contrast, in the periapical region, a marked reduction was observed in extra-root infection, possibly due to the combined action of hydroxyl ions and chlorhexidine, diffusing passively through the apical foramen, or as a result of small periapical extrusions.

\section{REFERENCES}

1. Barthel CR, Zimmer S, Zilliges S, Schiller R, Göbel UB, Roulet JF. In situ antimicrobial effectiveness of chlorhexidine and calcium hydroxide: gel and paste versus gutta-percha points. J Endod 2002;28(6):427-30.

2. Bystrom A, Happonen RP, Sjogren U, Sundqvist U. Healing of periapical lesions of pulpless teeth after endodontic treatment with controlled asepsis. Endod Dent Traumatol 1987;3(2):58-63.

3. Dalton BC, Orstavik D, Phillips C, Pettiette M, Trope M. Bacterial reduction with nickel-titanium rotary instrumentation. J Endod 1998;24(11):763-7.

4. Delany GM, Patterson SS, Miller CH, Newton CW. The effect of chlorhexidine gluconate irrigation on the root canal flora of freshly extracted necrotic teeth. Oral Surg Oral Med Oral Pathol 1982;53(5):518-23.

5. Gomes BPFA, Ferraz CCR, Vianna ME, Berber VB, Teixeira FB, Souza-Filho FJ. In vitro antimicrobial activity of several concentrations of sodium hypochlorite and chlorhexidine gluconate in the elimination of Enterococcus faecalis. Int Endod J 2001;34(6):424-8.

6. Gomes BPFA, Souza SF, Ferraz CCR, Teixeira FB, Zaia AA, Valdrighi L, et al. Effectiveness of $2 \%$ chlorhexidine gel and calcium hydroxide against Enterococcus faecalis in bovine root dentine in vitro. Int Endod J 2003;36(4):267-75.

7. Heling I, Steinberg D, Kenig S, Gavrilovich I, Sela MN, Friedman M. Efficacy of a sustained-release device containing chlorhexidine and $\mathrm{Ca}(\mathrm{OH})_{2}$ in preventing secondary infection of dentinal tubules. Int Endod J 1992;25(1):20-4.
Since the clinical, radiographic and histological success of endodontic treatment of teeth with necrotic pulp and radiolucent periapical areas are strongly influenced by the level of reduction or elimination of intracanal and extraradicular infection $^{2}$, it may be that the adequate automated biomechanical preparation associated with the application of calcium hydroxide + chlorhexidine paste for 21 days, represents a promising alternative in the conservative resolution of chronic periapical pathoses of endodontic origin.

\section{CONCLUSIONS}

According to the results obtained, the rotary chemo-mechanical preparation associated with a $5.25 \%$ solution of sodium hypochlorite, combined with the application of an intracanal medication with calcium hydroxide and $2 \%$ chlorhexidine digluconate for 21 days, offers a satisfactory antiseptic effect since it significantly reduces the intracanal microbiota, as well as the incidence of periapical biofilms. Further research involving one-visit endodontics should be undertaken in order to compare the results.

8. Jeansonne MJ, White RR. A comparison of $2.0 \%$ chlorhexidine gluconate and $5.25 \%$ sodium hypochlorite as antimicrobial endodontic irrigants. J Endod 1994;20:276-8.

9. Jenkins S, Addy M, Wade W. The mechanism of action of chlorhexidine - A study of plaque growth on enamel inserts in vivo. J Clin Periodontol 2002;15(7):415-24.

10. Komorowski R, Grad H, Wu XY, Friedman S. Antimicrobial substantivity of chlorhexidine-treated bovine root dentin. J Endod 2000;26(6):315-7.

11. Leonardo MR, Almeida WA, Ito IY, Silva LAB. Radiographic and microbiologic evaluation of posttreatment apical and periapical repair of root canals of dogs' teeth with experimentally induced chronic lesion. Oral Surg Oral Med Oral Pathol 1994;78(2):232-8.

12. Leonardo MR, Silva LAB, Rossi MA, Ito IY, Bonifácio KC. Evaluation of biofilm and microorganisms on the external root surface in human teeth. J Endod 2002;28(12):815-8.

13. Leonardo MR, Silva LAB, Tanomaru Filho M, Bonifácio $\mathrm{KC}$, Ito IY. In vitro evaluation of antimicrobial activity of sealers and pastes used in endodontics. J Endod 2000;26(7):391-4.

14. Leonardo MR, Tanomaru Filho M, Silva LAB, Nelson Filho $\mathrm{P}$, Bonifácio KC, Ito IY. In vivo antimicrobial activity of $2 \%$ chlorhexidine used as a root canal irrigating solution. J Endod 1999;25(3):167-71.

15. Lomçali G, Sen BH, Çankaya H. Scanning electron microscopic observations of apical root surfaces of teeth with apical periodontitis. Endod Dent Traumatol 1996;12(2):70-6. 
Soares JA, Leonardo MR, Silva LAB, Tanomaru Filho M, Ito IY. Effect of rotary instrumentation and of the association of calcium hydroxide and chlorhexidine on the antisepsis of the root canal system in dogs. Braz Oral Res 2006;20(2):120-6.

16. Menezes MM, Valera MC, Jorge AO, Koga-Ito CY, Camargo $\mathrm{CH}$, Mancini MN. In vitro evaluation of the effectiveness of irrigants and intracanal medicaments on microorganisms within root canals. Int Endod J 2004;37(5):311-9.

17. Nerwich A, Fidgor D, Endo D, Messer HH. pH changes in root dentin over a 4-week period following root canal dressing with calcium hydroxide. J Endod 1993;19(6):302-6.

18. Orstavik D, Kerekes K, Molven O. Effects of extensive apical reaming and calcium hydroxide dressing on bacterial infection during treatment of apical periodontitis: a pilot study. Int Endod J 1991;24(1):1-7.

19. Peters LB, Wesselink PR, Buijs JF, van Winkelhoff AJ. Viable bacteria in root dentinal tubules of teeth with apical periodontitis. J Endod 2001;27(2):76-81.

20. Portenier I, Haapasalo H, Rye A, Waltimo T, Orstavik $\mathrm{D}$, Haapasalo M. Inactivation of root canal medicaments by dentine, hydroxyl apatite and bovine serum albumin. Int Endod J 2001;34(3):184-8.

21. Quillin B, Dabirsiaghi CL, Krywolap GN, Dumsha TC. Antimicrobial effect of $\mathrm{Ca}(\mathrm{OH})_{2}$ supplemented with metronidazole and chlorhexidine as intracanal medicaments. J Endod 1992;18:187.

22. Silva LAB, Nelson-Filho P, Leonardo MR, Rossi MA, Pansani CA. Effect of calcium hydroxide on bacterial endotoxin in vivo. J Endod 2002;28(2):94-8.

23. Siqueira JF Jr, Lopes HP. Mechanisms of antimicrobial activity of calcium hydroxide: a critical review. Int Endod J 1999;32(5):361-9.

24. Siqueira JF Jr, Uzeda M. Intracanal medicaments: evaluation of the antibacterial effects of chlorhexidine, metronidazole, and calcium hydroxide associated with three vehicles. J Endod 1997;23(3):167-9.

Received for publication on Dec 20, 2004

Sent for alterations on Sep 01, 2005

Accepted for publicaton on Mar 27, 2006 